\title{
자발대뇌공기색전중
}

\author{
김래영 천상명 나현욱 \\ 동아대학교 의과대학 신경과학교실
}

\section{Spontaneous Cerebral Air Embolism}

\author{
Rae Young Kim, MD, Sang-Myung Cheon, MD, Hyun-Wook Nah, MD \\ Department of Neurology, Dong-A University College of Medicine, Busan, Korea
}

J Korean Neurol Assoc 35(4):268-269, 2017

급성림프모구백혈병(acute lymphoblastic leukemia)으로 진단된 51세 여성이 고열증상으로 입원하였다. 광범위한 폐렴과 혈청 갈 락토마난측정(galactomannan assay)에서 양성을 보여 폐아스페르 길루스증으로 진단하고, 치료를 시작하였다. 입원 26일째에 환자 는 화장실에서 배변 중 쓰러졌다. 혈압 $68 / 41 \mathrm{mmHg}$, 산소포화도 $70 \%$ 대였으며, 의식은 반혼수상태였다. 뇌 컴퓨터단층촬영에서 피 질혈관에 공기색전증이 나타났다(Fig. A). 환자는 활력징후가 불안 정하여 고압산소 치료는 시행하지 못하였다. 2 시간 후 동공반사가 소실되어 시행한 추적영상에서 두개내혈관에 광범위한 공기색전 증 소견이 나타났다(Fig. B). 3 시간 후 환자는 사망하였다.

공기색전증은 대부분 의인성으로 발생하나, ${ }^{1}$ 본 환자에서는 증
상 발생 전에 외상, 인공호흡, 침습적 시술 등이 없었고, 중심정맥 관을 가지고 있었으나 단절되는 사건이 발생하지 않았다. 배변활 동 중 발살바수기를 하였을 가능성이 높고, 의인성 원인이 배제되 어 폐아스페르길루스증(Fig. C)이 폐정맥을 침범하여 발생한 자발 대뇌공기색전증으로 추정하였다. ${ }^{2}$

\section{REFERENCES}

1. Muth CM, Shank ES. Gas embolism. N Engl J Med 2000;342:476-482.

2. Lin C, Barrio GA, Hurwitz LM, Kranz PG. Cerebral air embolism from angioinvasive cavitary aspergillosis. Case Rep Neurol Med 2014;2014:406106.

Received July 7, 2017 Revised August 8, 2017

Accepted August 8, 2017

Address for correspondence: Hyun-Wook Nah, MD

Department of Neurology, Dong-A University College of Medicine, 26 Daeshingongwon-ro, Seo-gu, Busan 49201, Korea

Tel: +82-51-240-2615 Fax: +82-51-244-8338

E-mail: bluream@empal.com 

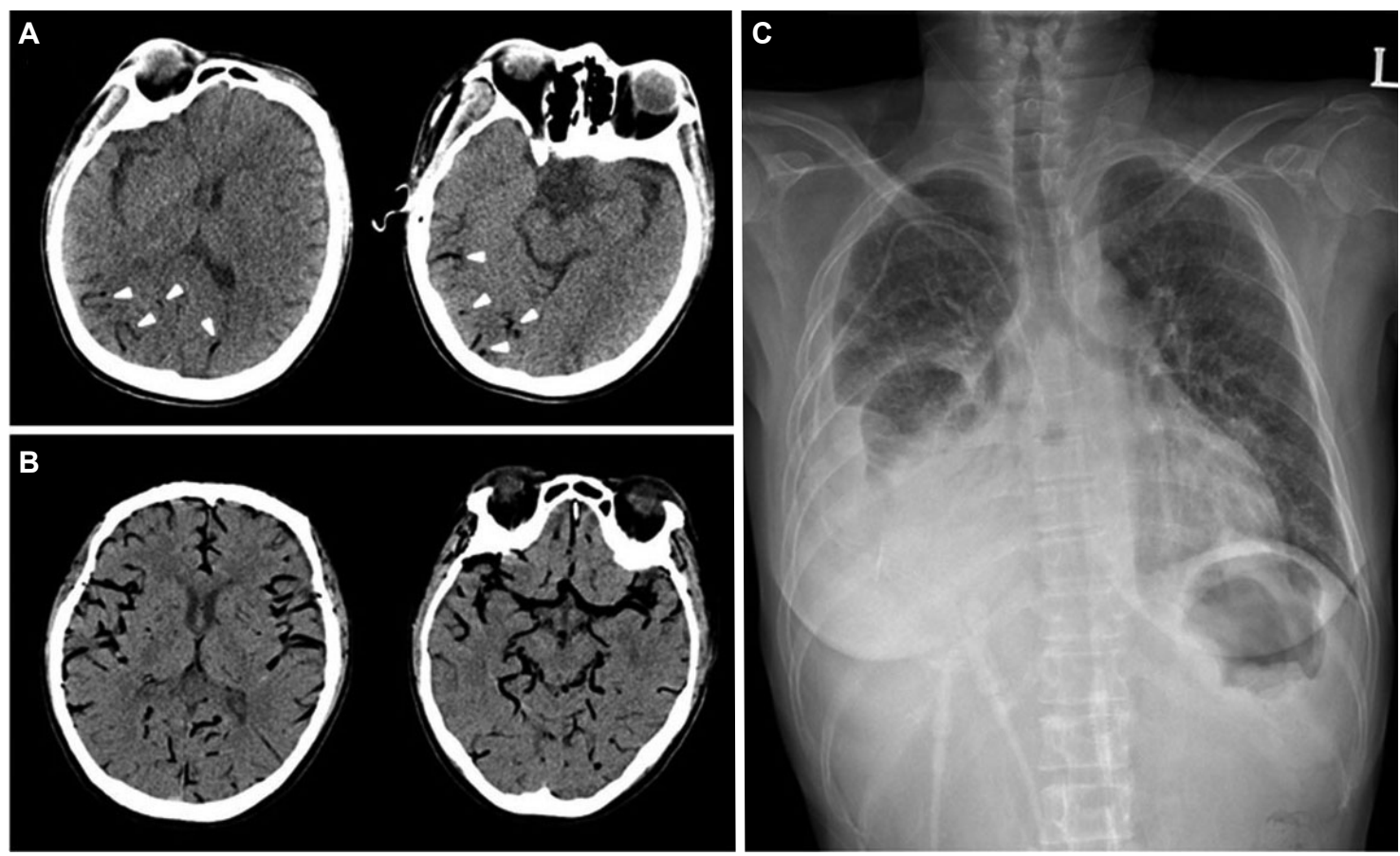

Figure. Brain CT scans and chest x-ray of the patient. The initial non-enhanced brain CT (A) taken 20 minutes after symptom reveals air entrapment in cortical vessels (arrowheads). The follow-up CT (B) obtained 2 hours later shows extensive air densities along the cerebral arteries and veins, including the circle of Willis and the pial vessels. No definite brain parenchymal lesion is noted. The chest $\mathrm{X}$-ray $(\mathrm{C})$ taken one day before the event shows marked volume loss and consolidation in right middle and lower lobes. CT; computed tomography. 